\title{
Isolation and characterization of plant growth promoting bacteria (PGPB) from anaerobic digestate and their effect on common wheat (Triticum aestivum) seedling growth
}

\author{
Guangdou Qi ${ }^{1}$, Zhifei Pan $^{2}$, Fetra J. Andriamanohiarisoamanana ${ }^{3}$, Takaki Yamashiro ${ }^{4}$, \\ Masahiro Iwasaki $^{5}$, Keiko Kawamoto ${ }^{6}$, Kazutaka Umetsu ${ }^{7 *}$ \\ ${ }^{1-5,7}$ Department of Animal and Food Hygiene, Obihiro University of Agriculture and Veterinary Medicine, Japan \\ ${ }^{6}$ Department of Veterinary Medicine, Obihiro University of Agriculture and Veterinary Medicine, Japan
}

\begin{abstract}
The use of anaerobic digestate as fertilizer is considered beneficial since it provides plant nutrients and organic matter to soils. However, there is limited information about plant growth promoting bacteria (PGPB) in digestate. In this study, we isolated Bacillus and Pseudomonas from two types of anaerobic digestates, and selected three different plant growth promoting traits and antifungal activity to screen 200 bacteria isolated from each digestate. Then 6 isolates based on plant growth promoting traits were selected and inoculated with common wheat seeds to evaluate their plant growth promoting activity. Cultivable population of Bacillus and Pseudomonas were $2.20 \times 10^{6}$ and $6.98 \times 10^{4} \mathrm{CFU} \mathrm{g^{-1 }}$ dry matter in mesophilic digestate, while were $6.86 \times 10^{5}$ and $5.65 \times 10^{4} \mathrm{CFU} \mathrm{g}^{-1}$ dry matter in thermophilic digestate. Twenty-five bacterial isolates from mesophilic digestate and 12 bacterial isolates from thermophilic digestate showed positive plant growth promoting traits or antifungal activity. In plant growth promoting assay, all isolates significantly promoted growth of wheat seedlings $(p<0.05)$. Seedlings stem length was increased from $28.5 \%$ to $38.6 \%$ by bacteria inoculation. In addition, bacteria inoculation increased seedlings stem weight from $113.3 \%$ to $214.2 \%$ and root weight from $108.6 \%$ to $207.2 \%$ as compared to un-inoculated control. The results showed that anaerobic digestate was a potential source for isolation of $P G P B$, and $P G P B$ in digestate would be beneficial for plant growth with fertilizer application.
\end{abstract}

Keywords- Anaerobic digestate, Plant growth promoting bacteria (PGPB), Bacillus, Pseudomonas, Common wheat (Triticum aestivum).

\section{INTRODUCTION}

Anaerobic digestion of organic wastes produces biogas and a nutrient-rich digestate. Digestate contains partially-degraded organic matter, inorganic plant nutrients and microbial biomass, therefore it can be used as soil conditioner or fertilizer on agricultural field (Alburquerque et al., 2012). The use of digestate as a fertilizer is considered eco-friendly since it recycles plant nutrients in the organic waste and thus reduces large scale use of chemical fertilizers. Furthermore, plant nutrients are present in inorganic plant-available forms in digestate at a markedly higher level compared to undigested organic wastes, because of the mineralization of organic nutrients during anaerobic digestion process (Umetsu et al., 2002). Previous researches have documented the beneficial effects of digestate as organic fertilizer on plant growth and nutrients uptake, and soil structure and microbial activity (Muscolo et al., 2017; Risberg et al., 2017; Solé-Bundó et al., 2017; Tampio et al., 2016).

Plant growth promoting bacteria (PGPB) represent a wide variety of bacteria, which occupy the rhizosphere of many plant species and promote host plant growth directly by solubilizing minerals such as phosphorus, producing siderophores that chelate iron and producing phytohormones (Grobelak et al., 2015). Phosphorus (P) is one of the major macronutrients required for growth and development of plant. Generally, soils have large reserves of total $\mathrm{P}$, but the amount available to plants is low as majority of soil P is found in insoluble forms (Ahemad and Kibret, 2014; Vessey, 2003). PGPB could make phosphorus available to plants by solubilizing and mineralizing inorganic and organic phosphorus in soils (Ahemad and Kibret, 2014). Iron is also an essential nutrient plant growth. However, iron exists mainly as $\mathrm{Fe}^{3+}$ in aerobic environment and is likely to form insoluble hydroxides and oxyhydroxides which are not unavailable to plants (Rajkumar et al., 2010). The siderophores, which are low-molecular mass iron chelators, secreted by some PGPB could solubilize iron from minerals or organic compounds under conditions of iron limitation to make iron accessible to plants (Indiragandhi et al., 2008). Indole-3acetic acid (IAA) is the primary phytohormone produced by RGPB and has various effects on plant growth promotion such as cell division and elongation, stimulation of seed germination, and increase root development (Ahemad and Kibret, 2014). PGPB can also stimulate plant growth indirectly by suppressing phytopathogens in forms of producing antibiotics, siderophores, and fungal cell wall-lysing enzymes (Ji et al., 2014). The largest groups of PGPB are Pseudomonas, Bacillus, Enterobacter, and Erwinia (Grobelak et al., 2015). Majority of researched PGPB are isolated from rhizosphere and they are 
generally known as plant growth promoting rhizobacteria (PGPR) (Khalid et al., 2004). However, anaerobic digestates are host to numerous PGPB and little attention has been focused on the isolation and characterization of PGPB from anaerobic digestate.

In the present study, two groups of PGPB: Bacillus and Pseudomonas isolated from two types of anaerobic digestate were screened on plant growth promoting traits including phosphate solubilization, siderophore production and phytohormone production, as well as antifungal activity. Selected bacterial isolates were further evaluated for their growth promoting activity on common wheat (Triticum aestivum).

\section{MATERIAL AND METHOD}

2.1

Anaerobic digestate samples collection

Anaerobic digestate samples were collected from two continuously stirred tank reactors (CSTR) (Yamashiro et al., 2013) operated at mesophilic $\left(37^{\circ} \mathrm{C}\right)$ and thermophilic $\left(55^{\circ} \mathrm{C}\right)$ temperatures. Mesophilic and thermophilic digesters were fed daily with dairy manure. To ensure homogeneity of samples, digesters were thoroughly stirred before digestate samples were collected. Mesophilic and thermophilic digestates collected from the digesters were thereafter referred to as MAD and TAD, respectively. Digestate samples were immediately kept at $4{ }^{\circ} \mathrm{C}$ and isolation of bacteria was done within $24 \mathrm{~h}$.

\subsection{Isolation of bacteria from anaerobic digestate samples}

Bacillus and Pseudomonas were isolated by the spread plate method. Samples were diluted 10-fold with phosphate buffered saline (pH 7.4), and $100 \mu \mathrm{l}$ of diluent was spread on BD BBL ${ }^{\mathrm{TM}}$ MYP (BD Falcon ${ }^{\mathrm{TM}}$, Franklin Lakes, NJ, USA) plates to isolate Bacillus, and Difco ${ }^{\text {TM }}$ Cetrimide Agar Base (Becton, Dickinson and Company, Sparks, MD, USA) plates to isolate Pseudomonas, respectively. After incubation, typical colonies were counted and calculated as colony forming units per gram of dry matter (CFU g ${ }^{-1}$ dry matter). Then one-hundred Bacillus isolates and one-hundred Pseudomonas isolates of each digesate sample were selected randomly and maintained on the LB agar plates for further analyses.

\subsection{Screening of bacterial isolates for plant growth promoting traits and antifungal activity}

Phosphate solubilization ability of bacterial isolates was determined with a Pikovskaya's agar plate (HiMedia Laboratories Ltd, Mumbai, India). Bacterial strains were spotted on Pikovskaya's agar plate and incubated at $28^{\circ} \mathrm{C}$ for 3 days. The isolates which produced a halo zone around the colony was determined as having ability to solubilize phosphate.

Chrome Azurol Sulphonate (CAS) assay was used to detect siderophore production of bacterial isolates. The CAS agar plate was made according to method described by Lakshmanan et al. (2015). Bacterial isolates were spotted on CAS agar and incubated at $28^{\circ} \mathrm{C}$ for 3 days. Formation of orange halo around the colonies confirmed the production of siderophore.

IAA (indole-3-acetic acid) production of bacterial isolates was determined according to the method previously described by $\mathrm{Ji}$ et al. (2014). Bacterial strains were inoculated into $5 \mathrm{ml} \mathrm{LB}$ broth with $0.1 \%$ (w/v) L-tryptophan and incubated on a rotary shaker at $150 \mathrm{rpm}$ for 3 days at $30^{\circ} \mathrm{C}$. The cultures were centrifuged at $10,000 \mathrm{rpm}$ for 10 min at $4{ }^{\circ} \mathrm{C}$ to obtain a supernatant. The supernatant $\left(2 \mathrm{ml}\right.$ ) was mixed with $4 \mathrm{ml}$ of Salkowski's reagent $\left(2 \mathrm{ml} 0.5 \mathrm{M} \mathrm{FeCl}_{3}\right.$ and $98 \mathrm{ml} 35 \%$ perchloric acids) and incubated for 25-30 min in the dark at room temperature. The development of a pink color indicates IAA production, and optical density of mixtures was read at $530 \mathrm{~nm}$ with a spectrophotometer (NanoDrop2000c, Thermo Scientific). The concentrations of IAA produced per milliliter of culture $\left(\mu \mathrm{g} \mathrm{ml}^{-1}\right)$ were estimated by comparison with a standard curve of IAA in the range of $0.5-100 \mu \mathrm{g} \mathrm{ml}^{-1}$.

Antifungal activity of bacterial isolates was tested using the dual culture method with Potato Dextrose Agar (PDA, Becton, Dickinson and Company, Sparks, MD, USA). In this study, the fungal strain Fusarium nivale f. sp. graminicola (MAFF 235153) purchased from National Institute of Agrobiological Sciences, Japan (NIAS; Tsukuba, Japan) was used. The fungal mycelia were inoculated in the center of a PDA agar plate and incubated for $24 \mathrm{~h}$ at $25^{\circ} \mathrm{C}$ followed by inoculation of the isolates $3 \mathrm{~cm}$ away from the center of the PDA plate. The fungal mycelium alone was inoculated as a control. After incubation at $28^{\circ} \mathrm{C}$ for 7 days, the antifungal activity was measured by the percent of inhibition of growth $(\mathrm{PGI})$ : PGI $=(1-$ $\mathrm{R} / \mathrm{Rc}) \times 100 \%$, where $\mathrm{R}$ represents the radius of the fungal mycelia in the plate inoculated with bacteria isolates, and $\mathrm{Rc}$ represents the radius of the fungal mycelia in the control plate.

\section{$2.4 \quad$ Identification of bacteria isolates}

For identification of bacterial isolates, Bruker microflex mass spectrometer system (microflex LT/SH, Bruker Daltonics, Kanagawa, Japan) was used. Two methods, direct smear method and on-plate extraction method were used in this study. For 
the former method, bacterial colony was directly smeared onto a spot on polished steel MALDI target plates using sterile toothpicks. Thin spots of bacteria were then dried in a safety cabinet, and subsequently overlaid with $1 \mu$ l of the matrix solution, comprising a HCCA ( $\alpha$-Cyano-4-hydroxycinnamic acid) matrix (Bruker Daltonik) for 5 min. For the on-plate extraction method, an extraction step by $1 \mu 1$ of $70 \%$ formic acid (Wako Pure Chemical Industries, Osaka, Japan) was introduced before cocrystallization with the matrix. Escherichia coli (K-12, laboratory stock) was used as a positive and quality control, and formic acid and the matrix was used as negative control at each run. The Bacterial Test Standards (Bruker Daltonics) was used for instruments calibration with each run. The samples prepared by each method were subjected to the microflex mass spectrometer, and results were analyzed by MALDI Biotyper 3.0 software (Bruker Daltonics).

\subsection{Plant growth promoting assay with common wheat (Triticum aestivum)}

Plant growth promoting assay with common wheat was conducted as described by Grobelak et al. (2015). The seeds of common wheat (Triticum aestivum) were surface sterilized with $1.5 \%$ (v/v) sodium hypochlorite for 10 min and washed with sterile water for 3 times. Subsequently, sterilized seeds were planted in plastic pots filled with $100 \mathrm{~g}$ of commercial soil which was sterilized by autoclave. Bacterial isolates were incubated in LB broth at $30^{\circ} \mathrm{C}$ for 3 days and 150 rpm in a rotary shaker. Then, the bacterial cultures were centrifuged at $6000 \mathrm{rpm}$ for $10 \mathrm{~min}$, cell pellets were suspended in sterile water and densities were adjusted to $1 \times 10^{8} \mathrm{CFU} \mathrm{ml}^{-1}$. The bacterial suspensions were applied immediately after seeding with $1 \mathrm{ml}^{-} \mathrm{pot}^{-}$ ${ }^{1}$. Only sterile water was applied as control. Pots were maintained at room temperature $\left(26-28^{\circ} \mathrm{C}\right)$ for 4 weeks with five replicates, and then stems and roots of the plants were weighed for biomass determination and length of the plants was also measured.

\subsection{Statistical analysis}

Results are expressed as mean values \pm standard deviation. Data from plant growth promoting assay were statistically analyzed by analysis of variance (ANOVA) with treatment means separated by Tukey test at $p<0.05$ using SAS Statistical Software version 9.4 (SAS Institute Inc., USA).

\section{RESULTS AND DISCUSSION}

\subsection{Isolation and characterization of bacteria for plant growth promoting traits and antifungal activity}

Cultivable population of Bacillus and Pseudomonas were $2.20 \times 10^{6}$ and $6.98 \times 10^{4} \mathrm{CFU} \mathrm{g}^{-1} \mathrm{dry}$ matter in MAD, which were higher than $6.86 \times 10^{5}$ and $5.65 \times 10^{4} \mathrm{CFU} \mathrm{g}^{-1}$ dry matter in TAD. Then 100 Bacillus isolates and 100 Pseudomonas isolates were selected from each digestate sample and screened for plant growth promoting traits and antifungal activity. The results are presented in Table 1. Twelve Bacillus isolates (12\%) from the MAD showed siderophores production and antifungal activity, in which 5 isolates also showed IAA production. Thirteen Pseudomonas isolates (13\%) showed siderophores and IAA production, in which only one isolate showed phosphate solubilization. For Bacillus isolates from TAD, only 5 isolates (5\%) were positive for plant growth promoting traits or antifungal activity, and 7 Pseudomonas isolates (7\%) produced IAA in which 6 isolates also showed siderophores production.

It is known that anaerobic digestion process inactivates bacteria in feedstock due to many factors, such as reactor temperature, feedstock retention time, and digestate $\mathrm{pH}$ (Smith et al., 2005; Wagner et al., 2008). Thermophilic temperature causes greater inactivation of bacteria than mesophilic temperature (Iwasaki et al., 2011), which explains higher cultivable bacteria and percent of PGPB observed in MAD than in TAD.

\section{TABLE 1}

Number of BaCterial Isolates Showed Plant Growth Promoting Traits and ANTifungal ACTIVITY FROM ANAEROBIC DIGESTATES

\begin{tabular}{|c|c|c|c|c|c|}
\hline \multirow{2}{*}{ Sample } & Bacterial genus & $\begin{array}{c}\text { Phosphate } \\
\text { solubilization }\end{array}$ & $\begin{array}{c}\text { Siderophores } \\
\text { production }\end{array}$ & IAA production & $\begin{array}{c}\text { Antifungal } \\
\text { activity }\end{array}$ \\
\hline \multirow{2}{*}{ MAD } & Bacillus & 0 & 12 & 5 & 12 \\
\cline { 2 - 6 } & Pseudomonas & 1 & 13 & 3 & 0 \\
\hline \multirow{2}{*}{ TAD } & Bacillus & 0 & 4 & 7 & 5 \\
\cline { 2 - 6 } & Pseudomonas & 0 & 6 & 0 \\
\hline
\end{tabular}

MAD: Mesophilic anaerobic digestate; TAD: Thermophilic anaerobic digestate; IAA: Indole-3 acetic acid. 
For plant growth promoting assay, 6 bacterial isolates were selected and their plant growth promoting traits and antifungal activity are presented in Table 2. Bacteria capable of phosphate solubilization are known to promote plant growth by increasing phosphorous uptake. The phosphate solubilizing isolate (MAD-21) was identified as Pseudomonas putida. Similarly, phosphate solubilizing ability of Pseudomonas putida has been reported in previous studies (Malboobi et al., 2009; Pandey et al., 2006). Fluorescent pseudomonads are considered to be one of the most promising groups of PGPB (Bhattacharyya and Jha, 2012). In this study, fluorescent pseudomonads isolate (MAD-17) showed siderophores production and IAA production of $17.3 \mu \mathrm{g} \mathrm{ml}^{-1}$, similar plant growth promoting traits of fluorescent pseudomonads were reported by Saber et al. (2015).

\section{TABLE 2}

Bacterial Isolates Selected for Plant Growth Promoting Assay

\begin{tabular}{|c|c|c|c|c|c|}
\hline $\begin{array}{c}\text { Bacterial } \\
\text { isolate no. }\end{array}$ & $\begin{array}{c}\text { Phosphates } \\
\text { solubilization }\end{array}$ & $\begin{array}{c}\text { Siderophores } \\
\text { production }\end{array}$ & $\begin{array}{c}\text { IAA production } \\
\left(\boldsymbol{\mu g} \mathbf{~ m}^{-1}\right)\end{array}$ & $\begin{array}{c}\text { Antifungal } \\
\text { activity (PGI\%) }\end{array}$ & Identification \\
\hline MAD-05 & - & + & $1.06 \pm 0.03$ & $62.75 \pm 2.45$ & Bacillus subtilis \\
\hline MAD-17 & - & + & $17.3 \pm 1.47$ & - & fluorescent pseudomonads \\
\hline MAD-21 & + & + & $18.43 \pm 1.0$ & Pseudomonas putida \\
\hline TAD-05 & - & - & $11.7 \pm 1.18$ & $43.53 \pm 2.35$ & Bacillus licheniformis \\
\hline TAD-11 & - & + & $11.59 \pm 0.28$ & - & Pseudomonas spp. \\
\hline TAD-12 & - & - & $24.54 \pm 1.24$ & - & Pseudomonas aeruginosa \\
\hline
\end{tabular}

MAD: Mesophilic anaerobic digestate; TAD: Thermophilic anaerobic digestate.

Phosphate solubilization (+); non phosphate solubilization (-). Siderophores production (+); non siderophores production

(-). IAA: Indole-3 acetic acid; values are expressed as means \pm standard deviation. PGI: percent of growth inhibition; values are expressed as means \pm standard deviation; non growth inhibition (-).

The production of phytohorrnones by bacteria is one of the most important factors of plant growth promotion (Ahemad and Kibret, 2014). Khalid et al. (2004) have categorized IAA-producing bacteria into three principal groups: lower producers (1 to $10 \mu \mathrm{g} \mathrm{ml}^{-1}$ ), medium producers $\left(11\right.$ to $20 \mu \mathrm{g} \mathrm{ml}^{-1}$ ) and higher producers (21 to $\left.30 \mu \mathrm{g} \mathrm{m}{ }^{-1}\right)$. Among 6 isolates for plant growth promoting assay, MAD-05 (Bacillus subtilis) was lower IAA producer (1.06 $\mu \mathrm{g} \mathrm{ml}^{-1}$ ), and TAD-12 (Pseudomonas aeruginosa) produced highest amount of IAA $\left(24.54 \mu \mathrm{g} \mathrm{ml}^{-1}\right)$, which was higher producer. The rest of isolates were medium producers (Table 2).

Biological control, or biocontrol means to control plant diseases by application of microorganisms, which is an environmental-friendly and efficient disease management approach (Ahemad and Kibret, 2014). In this study, Bacillus isolates (MAD-05, Bacillus subtilis and TAD-05, Bacillus licheniformis) showed high antifungal activity of $62.75 \%$ and 43.53\% PGI, which may contribute to the competition for space and nutrients and secretion of antifungal compounds (Yang et al., 2015). Similarly, Bacillus species have been widely reported to have antifungal activity against a wide variety of phytopathogens (Ji et al., 2014; Kumar et al., 2012; Liu et al., 2016). Therefore, further application of Bacillus isolates as biocontrol agents could be expected.

\subsection{Effect of bacteria inoculation on plant growth of common wheat (Triticum aestivum)}

The effects of selected bacterial isolates inoculation on plant growth were evaluated with common wheat (Fig. 1 and 2). Stem length of the seedlings inoculated with bacterial isolates (Fig. 2A) significantly increased from $28.5 \%$ to $38.6 \%$ compared to those of un-inoculated control $(p<0.05)$, and the differences between each treatments were non-significant $(p>0.05)$. Inoculation with MAD-21 (Pseudomonas putida), TAD-11 (Pseudomonas spp.) and TAD-12 (Pseudomonas aeruginosa) also significantly $(p<0.05)$ increased $51.8 \%, 50.1 \%$ and $59.21 \%$ of root length (Fig. 2A). The bacterial isolates inoculation further increased biomass of seedlings stem and root (Fig. 2B). Inoculation with TAD-12 (Pseudomonas aeruginosa) showed the highest increases in stem and root weight (214.2\% and $207.2 \%$, respectively) of the seedlings. After the TAD-12, other 5 bacterial isolates inoculation increased stem weight from $113.3 \%$ to $163.6 \%$, and root weight from $108.6 \%$ to $160.1 \%$ compared to un-inoculated control $(p<0.05)$. 


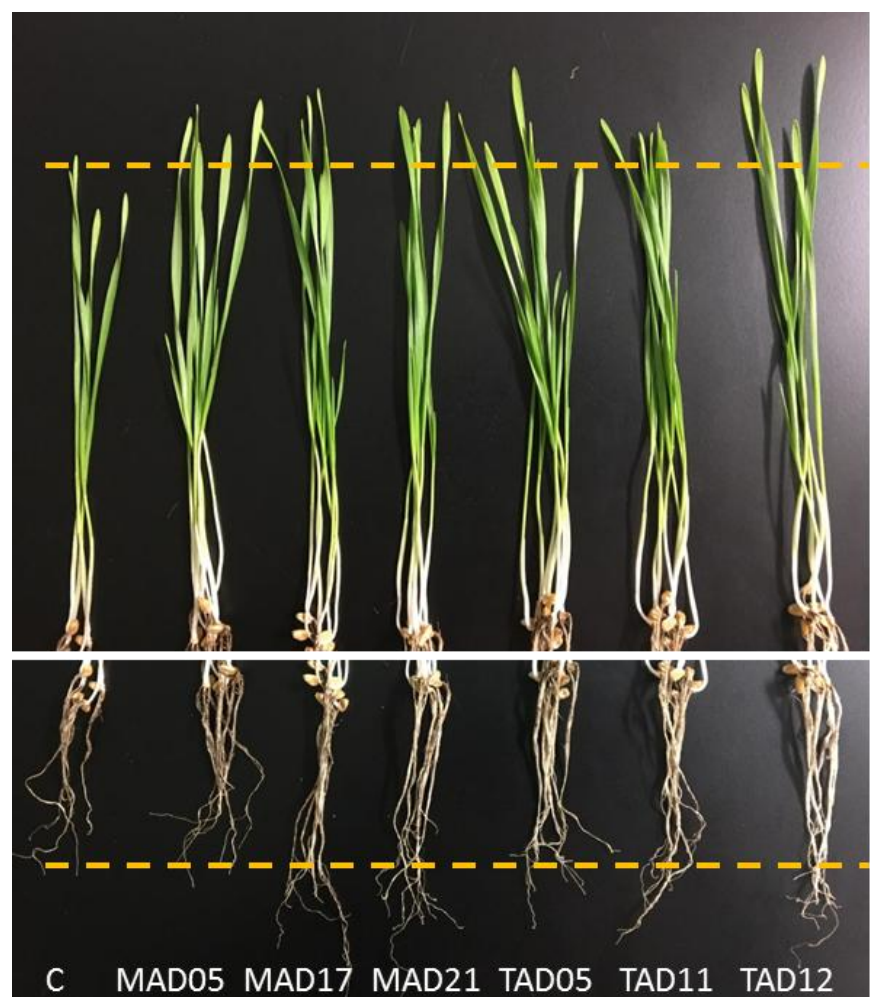

Fig.1. Plant Growth Promoting ASSay With CoMmon Wheat. C: UnTREated ConTrol; MAD-05: BACILLUS SUBTILIS; MAD-17: FLUORESCENT PSEUDOMONADS; MAD-21: PSEUDOMONAS PUTIDA; TAD-05: BACILLUS LICHENIFORMIS; TAD-11: PSEUDOMONAS SPP.; TAD-21: PSEUDOMONAS AERUGINOSA.

The inoculation of plants with PGPB increased plants length of stem and root, these results were agreement with observation of Balseiro-Romero et al. (2017) and Grobelak et al. (2015). It is well-known that inoculation with IAA-producing bacteria increases plant growth by promoting root growth and length, resulting in greater root surface area which enables the plant to absorb more nutrients from soils (Vessey, 2003). Inoculation with TAD-12 (Pseudomonas aeruginosa) showed the highest promotion in stem and root weight, which can be related with the highest production of IAA observed in the isolates (Table 3). Similarly, several researches have demonstrated that Bacillus and Pseudomonas strains produced IAA and are able to regulate root development (Ji et al., 2014; Kumar et al., 2012; Scagliola et al., 2016; Son et al., 2014).

It has been suggested that the performance of PGPB could be enhanced through the use of PGPB mixtures, and Dary et al. (2010) and Malboobi et al. (2009) have demonstrated that inoculation with mixed PGPB can promote plant growth more than a single strain. Although the effects of mixed PGPB inoculant were not investigated in this study, it could be expected that digestate is an inoculant of PGPB mixtures and promote plant growth more effective than single bacterial strain inoculant.

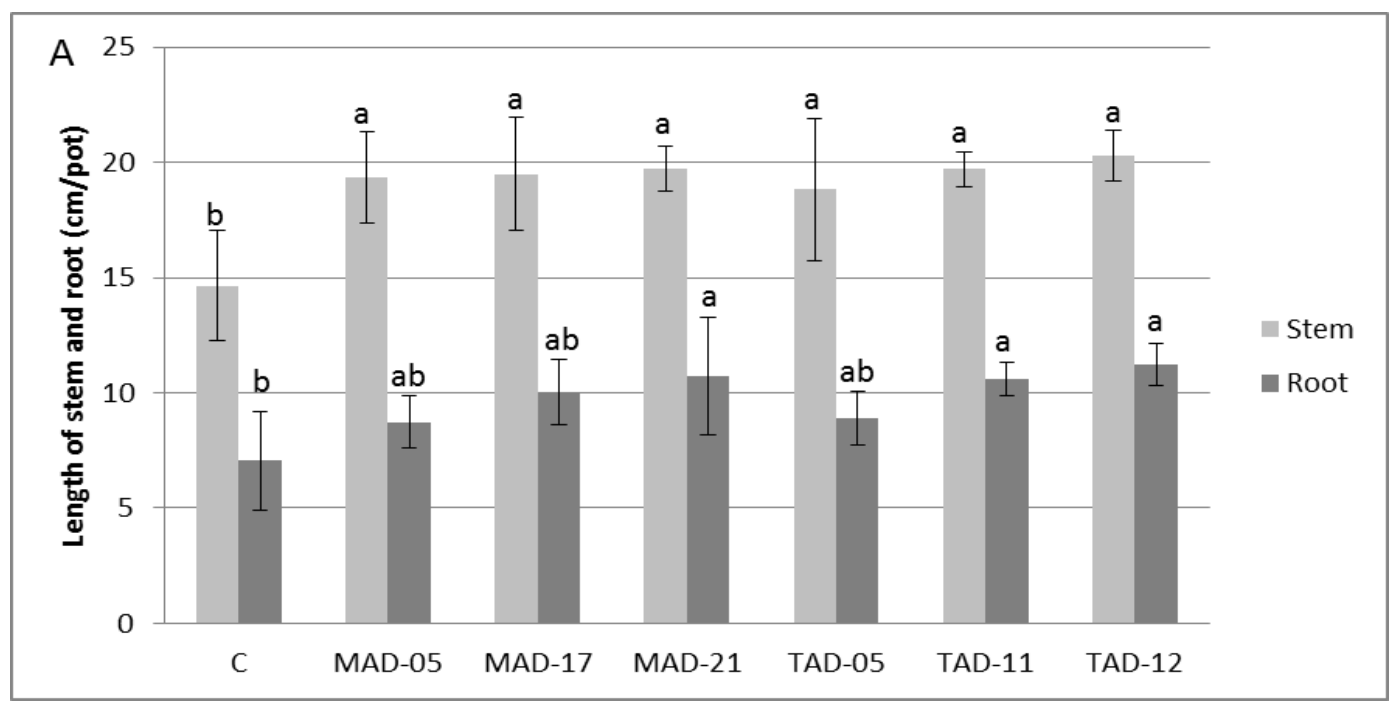




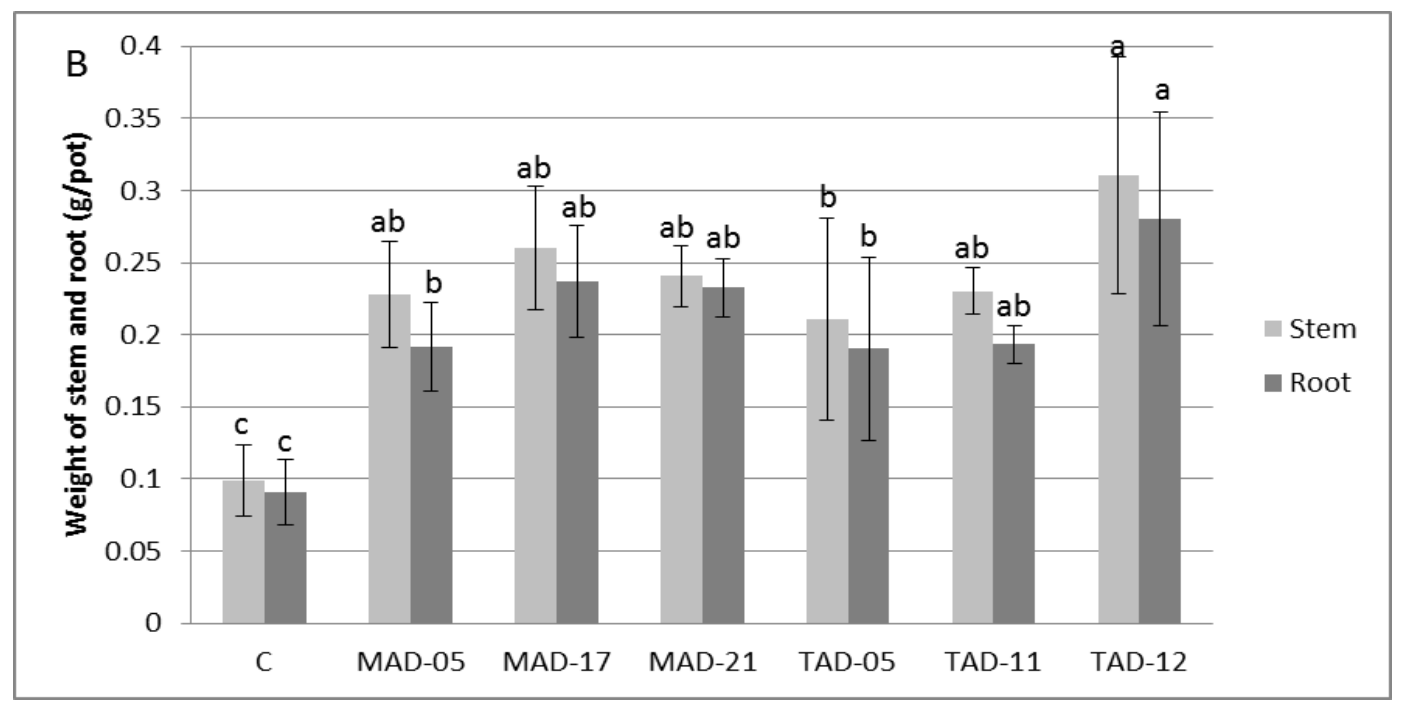

\section{Fig.2. STEM AND ROOT LENGTH (A) AND Weight (B) OF COMMON WHEAT SEEDLINGS INOCULATEd With Bacterial Isolates in Plant Growth Promoting ASSay. C: Untreated Control; MAD-05: BaCILLUS SUBTILIS; MAD-17: FLUORESCENT PSEUDOMONADS; MAD-21: PSEUDOMONAS PUTIDA; TAD-05: BACILLUS LICHENIFORMIS; TAD-11: PSEUDOMONAS SPP.; TAD-21: PSEUDOMONAS AERUGINOSA.}

\section{CONCLUSION}

In conclusion, anaerobic digestate is a large reservoir of bacteria capable of promoting plant growth. In this study, plant growth promoting Bacillus and Pseudomonas were isolated and characterized from mesophilic and thermophilic digestates. Two types of digesates contained different cultivable bacteria and percent of PGPB which may be attributed to the different operation temperature of digesters. Bacterial isolates showed plant growth promoting traits including phosphate solubilization, siderophores production and IAA production. The selected bacterial isolates significantly promoted plant growth, which is most probably due to their ability to produce IAA. These isolates can be applied as inoculants for improving plant growth. Bacillus isolates from digestates showed antifungal activity, therefore, it will be important to perform further studies investigating their antifungal activity in field experiments.

\section{ACKNOWLEDGEMENTS}

Authors are thankful to National Institute of Agrobiological Sciences (Tsukuba, Japan) for providing the fungal strain Fusarium nivale f. sp. graminicola. Authors are also grateful to the Scientific Research from the Ministry of Education, Culture, Sports, Science and Technology (MEXT) of Japan for Grant-in-Aid (No. 10670499).

\section{REFERENCES}

[1] Ahemad, M., Kibret, M., 2014. Mechanisms and applications of plant growth promoting rhizobacteria: Current perspective. J. King Saud Univ. - Sci. 26, 1-20.

[2] Alburquerque, J.A., de Fuente, C., Ferrer-Costa, A., Carrasco, L., Cegarra, J., Abad, M., Bernal, M.P., 2012. Assessment of the fertiliser potential of digestates from farm and agroindustrial residues. Biomass and Bioenergy 40, 181-189.

[3] Balseiro-Romero, M., Gkorezis, P., Kidd, P.S., Van Hamme, J., Weyens, N., Monterroso, C., Vangronsveld, J., 2017. Use of plant growth promoting bacterial strains to improve Cytisus striatus and Lupinus luteus development for potential application in phytoremediation. Sci. Total Environ. 581-582, 676-688.

[4] Bhattacharyya, P.N., Jha, D.K., 2012. Plant growth-promoting rhizobacteria (PGPR): Emergence in agriculture. World J. Microbiol. Biotechnol. 28, 1327-1350.

[5] Dary, M., Chamber-Pérez, M.A., Palomares, A.J., Pajuelo, E., 2010. "In situ” phytostabilisation of heavy metal polluted soils using Lupinus luteus inoculated with metal resistant plant-growth promoting rhizobacteria. J. Hazard. Mater. 177, 323-330.

[6] Grobelak, A., Napora, A., Kacprzak, M., 2015. Using plant growth-promoting rhizobacteria (PGPR) to improve plant growth. Ecol. Eng. 84, 22-28.

[7] Indiragandhi, P., Anandham, R., Madhaiyan, M., Sa, T.M., 2008. Characterization of plant growth-promoting traits of bacteria isolated from larval guts of Diamondback moth Plutella xylostella (Lepidoptera: Plutellidae). Curr. Microbiol. 56, $327-333$.

[8] Iwasaki, M., Yamashiro, T., Beneragama, N., Nishida, T., Kida, K., Ihara, I., Takahashi, J.I., Umetsu, K., 2011. The effect of 
temperature on survival of pathogenic bacteria in biogas plants. Anim. Sci. J. 82, 707-712.

[9] Ji, S.H., Gururani, M.A., Chun, S.C., 2014. Isolation and characterization of plant growth promoting endophytic diazotrophic bacteria from Korean rice cultivars. Microbiol. Res. 169, 83-98.

[10] Khalid, A., Arshad, M., Zahir, Z.A., 2004. Screening plant growth-promoting rhizobacteria for improving growth and yield of wheat. J. Appl. Microbiol. 96, 473-480.

[11] Kumar, P., Dubey, R.C., Maheshwari, D.K., 2012. Bacillus strains isolated from rhizosphere showed plant growth promoting and antagonistic activity against phytopathogens. Microbiol. Res. 167, 493-9.

[12] Lakshmanan, V., Shantharaj, D., Li, G., Seyfferth, A.L., Janine Sherrier, D., Bais, H.P., 2015. A natural rice rhizospheric bacterium abates arsenic accumulation in rice (Oryza sativa L.). Planta 242, 1037-1050.

[13] Liu, K., Garrett, C., Fadamiro, H., Kloepper, J.W., 2016. Induction of systemic resistance in Chinese cabbage against black rot by plant growth-promoting rhizobacteria. Biol. Control 99, 8-13.

[14] Malboobi, M.A., Behbahani, M., Madani, H., Owlia, P., Deljou, A., Yakhchali, B., Moradi, M., Hassanabadi, H., 2009. Performance evaluation of potent phosphate solubilizing bacteria in potato rhizosphere. World J. Microbiol. Biotechnol. 25, 1479-1484.

[15] Muscolo, A., Settineri, G., Papalia, T., Attinà, E., Basile, C., Panuccio, M.R., 2017. Anaerobic co-digestion of recalcitrant agricultural wastes: Characterizing of biochemical parameters of digestate and its impacts on soil ecosystem. Sci. Total Environ. 586, 746-752.

[16] Pandey, A., Trivedi, P., Kumar, B., Palni, L.M.S., 2006. Characterization of a phosphate solubilizing and antagonistic strain of Pseudomonas putida (B0) isolated from a sub-alpine location in the Indian Central Himalaya. Curr. Microbiol. 53, $102-107$.

[17] Rajkumar, M., Ae, N., Prasad, M.N.V., Freitas, H., 2010. Potential of siderophore-producing bacteria for improving heavy metal phytoextraction. Trends Biotechnol. 28, 142-149.

[18] Risberg, K., Cederlund, H., Pell, M., Arthurson, V., Schnürer, A., 2017. Comparative characterization of digestate versus pig slurry and cow manure - Chemical composition and effects on soil microbial activity. Waste Manag. 61, 529-538.

[19] Saber, F.M.A., Abdelhafez, A.A., Hassan, E.A., Ramadan, E.M., 2015. Characterization of fluorescent pseudomonads isolates and their efficiency on the growth promotion of tomato plant. Ann. Agric. Sci. 60, 131-140.

[20] Scagliola, M., Pii, Y., Mimmo, T., Cesco, S., Ricciuti, P., Crecchio, C., 2016. Characterization of plant growth promoting traits of bacterial isolates from the rhizosphere of barley (Hordeum vulgare L.) and tomato (Solanum lycopersicon L.) grown under Fe sufficiency and deficiency. Plant Physiol. Biochem. 107, 187-196.

[21] Smith, S.R., Lang, N.L., Cheung, K.H.M., Spanoudaki, K., 2005. Factors controlling pathogen destruction during anaerobic digestion of biowastes. Waste Manag. 25, 417-425.

[22] Solé-Bundó, M., Cucina, M., Folch, M., Tàpias, J., Gigliotti, G., Garfí, M., Ferrer, I., 2017. Assessing the agricultural reuse of the digestate from microalgae anaerobic digestion and co-digestion with sewage sludge. Sci. Total Environ. 586, 1-9.

[23] Son, J.S., Sumayo, M., Hwang, Y.J., Kim, B.S., Ghim, S.Y., 2014. Screening of plant growth-promoting rhizobacteria as elicitor of systemic resistance against gray leaf spot disease in pepper. Appl. Soil Ecol. 73, 1-8.

[24] Tampio, E., Salo, T., Rintala, J., 2016. Agronomic characteristics of five different urban waste digestates. J. Environ. Manage. 169, 293-302.

[25] Umetsu, K., Kondo, R., Tani, M., Hayashi, T., 2002. Fertilizer value of anaerobically co-digested dairy manure and food processing wastes, Greenhouse Gases and Animal Agriculture.

[26] Vessey, J.K., 2003. Plant growth promoting rhizobacteria as biofertilizers. Plant Soil 255, 571-586.

[27] Wagner, A.O., Gstraunthaler, G., Illmer, P., 2008. Survival of bacterial pathogens during the thermophilic anaerobic digestion of biowaste: Laboratory experiments and in situ validation. Anaerobe 14, 181-183.

[28] Yamashiro, T., Lateef, S.A., Ying, C., Beneragama, N., Lukic, M., Masahiro, I., Ihara, I., Nishida, T., Umetsu, K., 2013. Anaerobic co-digestion of dairy cow manure and high concentrated food processing waste. J. Mater. Cycles Waste Manag. 15, $539-547$.

[29] Yang, L., Quan, X., Xue, B., Goodwin, P.H., Lu, S., Wang, J., Du, W., Wu, C., 2015. Isolation and identification of bacillus subtilis strain YB-05 and its antifungal substances showing antagonism against gaeumannomyces graminis var. tritici. Biol. Control 85, 5258. 